\title{
Breast milk DHA levels in Sri Lankan mothers vary significantly in three locations that have different access to dietary fish
}

\author{
P S Lee ${ }^{1,3}$, V P Wickramasinghe ${ }^{2}$, S P Lamabadusuriya ${ }^{2}$, A W Duncan ${ }^{1}$, G Wainscott ${ }^{3}$, J D S K Weeraman ${ }^{4}$, \\ A S B Wijekoon ${ }^{5}, \mathrm{~K} \mathrm{H}$ Wong $^{3}$
}

(Index words: docosahexaenoeic acid, infant formula)

\begin{abstract}
Introduction Long-chain polyunsaturated fatty acids (LCPUFA) notably docosahexaenoeic acid (DHA) and arachidonic acid (ARA) are important for the optimum growth and development of the infant. DHA and ARA levels in breast-milk are thought to be influenced both by direct nutritional intake, and by the genetic variation of the FA desaturase enzymes.
\end{abstract}

Objectives To assess the fatty acid distribution in mothers' milk and their babies' blood, in three areas of Sri Lanka, with different access to sea-fish, and to see how the availability of dietary fish would affect fatty acid levels.

Methods 6-12 week-old mother-baby pairs were recruited and mother's dietary intake assessed. Packed RBC from infants and breast milk (BM) from mothers were transported on dry ice to the Nutrition Laboratory, University of Otago, New Zealand for fatty acids extraction and quantification.

Results We studied 136 mothers in three locations in Sri Lanka - Matara, Colombo, and Kandy. The breastmilk DHA levels were high in all three locations $(0.79 \%$, $0.53 \%$ and $0.37 \%$ respectively), and correlated with fish consumption. ARA levels did not vary significantly. In the 119 mother-infant pairs studied, infant erythrocyte DHA levels did not correlate significantly with BM DHA.

Conclusions Even the modest access to sea fish in the most inland site, resulted in BM-DHA levels higher than those found in any infant formula. Higher BM-DHA levels in the two other sites with greater access to fish did not lead to further increase in infant RBC-DHA levels. Where access to sea fish is limited, mothers should be encouraged to actively increase their fish intake as this would improve their DHA status, and also that of their breast milk.

Ceylon Medical Journal 2013; 58: 51-55

\section{Introduction}

In human nutrition, the two essential fatty acids (EFA) are $\omega$-6 linoleic acid (LA, 18:2n-6) and $\omega$-3 $\alpha$-linolenic acid (ALA, 18:3n-3). These two polyunsaturated fatty acids (PUFA) are solely plant-derived, and serve as the parent compounds from which humans (indeed, all vertebrates) make necessary long-chain polyunsaturated fatty acids
(LCPUFA) of the corresponding families. The LCPUFA are precursors for control molecules (e.g. eicosanoids), second messengers in signal transduction across cell membranes, and also facilitate membrane fluidity and hence function, this last being especially important in the retina and neuronal tissues where some LCPUFA are found in high concentrations. The availability of two specific LCPUFA, i.e. $\omega$-6 6 arachidonic acid (ARA, 20:4n-6) and $\omega$-3 docosahexaenoic acid (DHA, 22:6n-3) are now acknow-ledged to play a critical role in early growth and develop-ment, from pregnancy through infancy and beyond, not least because both are avidly accreted by the developing brain [1].

In maternal nutrition, ARA and DHA may either be absorbed pre-formed from different foods in the diet (e.g. ARA mainly from meat and eggs, DHA from oily fish and other seafood) or derived from conversion from their respective parent EFA by a series of alternating desaturation and chain-elongation steps. Three aspects may be relevant to our study. First, different vegetable oils are richer in different EFA e.g. sunflower and corn are rich in LA, soybean and walnut are rich in ALA, and coconut the main cooking oil in Sri Lanka is poor in both. Thus, varying dietary access and cultural practices may influence maternal EFA status. Second, the metabolic pathways involved in the desaturation and elongation of these two parent EFA share the same enzymes. Thus, high levels of LCPUFA formed in one (e.g. $\omega$-6) family may inhibit the synthesis of the corresponding compound in the other (e.g. $\omega$-3). Finally, genetic variations in the fatty-acid desaturase (FADS) gene clusters responsible for these desaturation enzymes may markedly influence their activity and hence an individual's resultant PUFA and LCPUFA status. This effect is reportedly much more apparent in the case of ARA, and only minimally so in the case of DHA (where dietary intake contributes much more to resulting LCPUFA status, than does metabolic conversion) [2].

In early infant nutrition, the entire EFA and part of the LCPUFA requirements are met directly by the contents of breast-milk (BM) or infant formula, but maternal EFA and LCPUFA status and BM levels are affected differently by diet. EFA are plant-derived, and therefore EFA levels in BM vary according to the mother's access to vegetable oils, with greater intake resulting in higher levels of both

${ }^{1}$ Department of Human Nutrition, University of Otago, Dunedin, New Zealand, ${ }^{2}$ Department of Paediatrics, University of Colombo, Sri Lanka, ${ }^{3}$ Mead Johnson Nutrition, Asia-Pacific Regional Office, Singapore, ${ }^{4}$ Department of Paediatrics, Teaching Hospital, Matara, Sri Lanka, ${ }^{5}$ Department of Paediatrics, University of Peradeniya, Sri Lanka.

Correspondence: VPW, e-mail: <pujithaw@yahoo.com>. Received 28 August 2012 and revised version accepted 4 January 2013. Competing interests: The study was funded by Mead-Johnson Nutritionals. See author affiliation too. 
$\omega-6$ and $\omega-3$ EFA. This was confirmed by a study of BM FA composition in vegans, vegetarians, and omnivores, which found that the mean LA level was significantly different in the three groups $(23.8 \%, 19.7 \%$, and $10.9 \%$ of total FA respectively), as was also that of ALA (1.36\%, 1.25\%, and $0.49 \%$ respectively) [3].

In contrast, BM LCPUFA is not significantly affected by access to vegetable oils, and in fact only DHA (and not ARA) is much affected by maternal diet. The same study found that vegan and vegetarian mothers had lower levels of BM DHA than omnivore mothers $(0.14 \%, 0.30 \%$ and $0.37 \%$ respectively), but there was no difference in ARA levels ( $0.32 \%, 0.38 \%$ and $0.35 \%$ respectively). The influence of this on the LCPUFA status of the infant was clear: 14-week-old breastfed infants of vegan mothers had less than a third the RBC-DHA levels (1.9\%) of those of omnivore mothers (6.2\%), while ARA concentrations were not different (13.3\% and $13.7 \%$ respectively) [3]. These results show that BM EFA levels are significantly influenced by plant-food sources and BM DHA (but not ARA) from animal-based foods.

Breast-milk levels of ARA are relatively constant, while DHA levels vary widely even across different populations. For example, one study of BM samples from nine countries reported a narrow range of 0.36 to $0.49 \%$ for ARA, and a much wider range of $0.17 \%$ to $0.99 \%$ for DHA [4]. A larger meta-analysis of BM composition that included 65 studies with 2,474 women, reported means (SD) of $0.47 \%$ (0.13) for ARA and 0.32\% (0.22) for DHA [5]. Variation in BM DHA levels is important, because these are related to infant DHA levels, both in plasma and RBC phospholipids, in a curvilinear way up to BM DHA levels of about $0.8 \%$ [6].

We therefore looked at the BM FA status of three groups of lactating women, and the corresponding RBC FA levels of their breast-fed infants, living in different parts of Sri Lanka with differing access to sea-fish. The study locations were the capital city Colombo (with ready availability of most foods), the hilly farming region of Kandy (with poorer access to fish) and the fishing port of Matara (where sea-fish would be both widely available and affordable). Plant-based foods were equally available in all three locations, and the predominant oil used in cooking was coconut oil.

\section{Methods}

We aimed to recruit fifty mother-baby pairs 6-12 weeks post-delivery from each of these three locations. Blood from infants was collected into a $75 \mu \mathrm{L}$ microhematocrit tube from a heel-prick. The tubes were centrifuged on site, the RBCs stabilized in an antioxidant mixture, and stored at $-20^{\circ} \mathrm{C}$ before being transported on dry ice to the Nutrition Laboratory, University of Otago, New Zealand. Breast milk was collected and stored at $-20^{\circ} \mathrm{C}$ before being transported in dry ice for analysis at the same laboratory.

BM lipids were extracted, isolated FA methylated, and the FA methyl esters separated using a 30 meter-long J\&W DB225 capillary column on HP5890 gas chromatographic system and Chem Station integration software. RBC total phospholipids were isolated with a neutral lipid TLC system, methylated, and extracted FA methyl esters separated isothermally and analysed as above. A composite standard made from commercially available methyl esters (NuCheck Prep, Elysian, Minnesota) served as reference. ALA, DHA and EPA were measured. The level of each FA was expressed as its percent of total FA.

The mothers' dietary intake of fish, meat, eggs and milk was assessed through recall, using a food frequency questionnaire, from which weekly average consumption (in number of portions) was evaluated. Inter-location variation was compared with one way ANOVA.

A separate sample of blood was taken to assess the TSH level to detect any hypothyroidism in these infants (as part of an incentive for joining the study) and all infants had normal levels. The ethical review committee of Faculty of Medicine, University of Colombo approved the research protocol and respective hospitals granted permission to conduct the study.

\section{Results}

Mother's of babies who were 6-12 months of age were invited at the time they visited the well baby clinics conducted at De Soyza Maternity Hospital, Colombo; Teaching Hospital, Matara and Teaching Hospital, Peradeniya. All mother's agreeing to participate were recruited till fifty mother-baby pairs were enrolled from each site. Breastmilk data from 136 mothers, RBC data from 127 infants were used in the final analysis. Data of 119 mother-infant matched pairs were available for the analysis.

Age, height, weight and BMI of all mothers are given in Table 1 . There were no significant difference in age and height in the 3 groups. The Kandy mothers were significantly heavier than those in Colombo and Matara; the BMI was also significantly higher than their Matara counterparts. Food consumption (mean portions of milk, meat, fish and egg per week per mother) is given in Table 1. Milk and meat consumption was significantly lower at Matara, while fish and egg consumption was significantly lower at Kandy. The mean age of all infants was $9.1 \pm 1.5$ weeks, and was significantly different at each location, with the highest in Kandy (9.9 weeks) and the lowest in Colombo (8.1 weeks).

BM FA levels are shown in Table 2. Monounsaturated FA was higher, and saturated FA lower, in BM from Colombo. These differences were small but statistically significant. Total $\omega$-3 FA were highest in Matara and lowest in Kandy, while total $\omega-6$ FA were not statistically different between groups.

Neither EFA (LA, ALA) differed between locations. Of the LCPUFA, $\omega$-6ARA did not differ between locations. However, the $\omega$-3 LCPUFAs (eicosapentaenoic acid (EPA) and DHA) differed significantly by location, it was highest in Matara, intermediate in Colombo, and lowest in Kandy. The differences in DHA levels were large: the highest mean BM DHA (0.79\% at Matara) was more than double the lowest mean (0.37\% at Kandy). Breast milk DHA levels showed significant positive association $(\mathrm{r}=0.30 ; p<0.001)$ with the number of weekly servings of fish but not with other food items (milk, $\mathrm{r}=-0.30 p=0.002$; meat, $\mathrm{r}=-0.145$ $p=0.132$; eggs, $\mathrm{r}=-0.148, p=0.123$ ). EPA levels showed a trend with fish that did not reach statistical significance $(\mathrm{r}=0.16, p=0.07)$.

Infant RBC FA levels are shown in Table 3. In contrast 
Table 1. Participant characteristics and frequency of consumption of major DHA containing food items

\begin{tabular}{|c|c|c|c|c|c|c|c|c|c|}
\hline & \multirow[t]{2}{*}{$\begin{array}{c}\text { All } \\
\mathrm{n}=136\end{array}$} & \multirow[t]{2}{*}{$\begin{array}{c}\text { Colombo } \\
\mathrm{n}=47\end{array}$} & \multirow[t]{2}{*}{$\begin{array}{c}\text { Kandy } \\
\mathrm{n}=44\end{array}$} & \multirow[t]{2}{*}{$\begin{array}{c}\text { Matara } \\
\mathrm{n}=45\end{array}$} & \multirow[t]{2}{*}{$\begin{array}{l}\text { ANOVA } \\
P \text { values }\end{array}$} & \multicolumn{4}{|c|}{$\begin{array}{c}\text { Unpaired } t \text { test } \\
\text { two-tailed } P \text { values }\end{array}$} \\
\hline & & & & & & & Colombo & Kandy & Matara \\
\hline $\begin{array}{l}\text { Age } \\
\text { (years) } \\
\text { mean (SD) }\end{array}$ & $\begin{array}{l}29.6 \\
(5.8)\end{array}$ & $30.2(6.0)$ & $\begin{array}{r}30.3 \\
(4.8)\end{array}$ & $\begin{array}{l}28.1 \\
(6.2)\end{array}$ & 0.122 & $\begin{array}{l}\text { Colombo } \\
\text { Kandy } \\
\text { Matara }\end{array}$ & $\begin{array}{l}0.93 \\
0.10\end{array}$ & $\begin{array}{l}0.93 \\
0.07\end{array}$ & $\begin{array}{l}0.10 \\
0.07\end{array}$ \\
\hline $\begin{array}{l}\text { Height } \\
(\mathrm{cm}) \\
\text { mean (SD) }\end{array}$ & $\begin{array}{c}153 \\
(7.4)\end{array}$ & $153(5.3)$ & $\begin{array}{c}154 \\
(9.1)\end{array}$ & $\begin{array}{l}153 \\
(7.8)\end{array}$ & 0.769 & $\begin{array}{l}\text { Colombo } \\
\text { Kandy } \\
\text { Matara }\end{array}$ & $\begin{array}{l}0.52 \\
1.00\end{array}$ & $\begin{array}{l}0.52 \\
0.58\end{array}$ & $\begin{array}{l}1.00 \\
0.58\end{array}$ \\
\hline $\begin{array}{l}\text { Weight (kg) } \\
\text { mean (SD) }\end{array}$ & $\begin{array}{c}55.3 \\
(10.6)\end{array}$ & $\begin{array}{c}55.3 \\
(10.9)\end{array}$ & $\begin{array}{c}60.0 \\
(11.6)\end{array}$ & $\begin{array}{l}51.6 \\
(8.0)\end{array}$ & 0.001 & $\begin{array}{l}\text { Colombo } \\
\text { Kandy } \\
\text { Matara }\end{array}$ & $\begin{array}{c}\mathbf{0 . 0 4 9} \\
0.07\end{array}$ & $\begin{array}{l}0.049 \\
0.00\end{array}$ & $\begin{array}{l}0.07 \\
\mathbf{0 . 0 0}\end{array}$ \\
\hline $\begin{array}{l}\text { BMI } \\
\left(\mathrm{kg} / \mathrm{m}^{2}\right) \\
\text { mean }(\mathrm{SD})\end{array}$ & $\begin{array}{l}23.5 \\
(3.9)\end{array}$ & $23.7(4.2)$ & $\begin{array}{l}25.0 \\
(3.9)\end{array}$ & $\begin{array}{l}22.1 \\
(3.2)\end{array}$ & 0.002 & $\begin{array}{l}\text { Colombo } \\
\text { Kandy } \\
\text { Matara }\end{array}$ & $\begin{array}{l}0.13 \\
\mathbf{0 . 0 4}\end{array}$ & $\begin{array}{l}0.13 \\
\mathbf{0 . 0 0}\end{array}$ & $\begin{array}{l}0.04 \\
0.00\end{array}$ \\
\hline $\begin{array}{l}\text { Milk intake } \\
\text { (ml per } \\
\text { week) }\end{array}$ & $\begin{array}{c}336 \\
(285)\end{array}$ & 467 (247) & $\begin{array}{c}457 \\
(304)\end{array}$ & $90(40)$ & 0.000 & $\begin{array}{l}\text { Colombo } \\
\text { Kandy } \\
\text { Matara }\end{array}$ & $\begin{array}{l}0.86 \\
\mathbf{0 . 0 0}\end{array}$ & $\begin{array}{l}0.86 \\
\mathbf{0 . 0 0}\end{array}$ & $\begin{array}{l}0.00 \\
0.00\end{array}$ \\
\hline $\begin{array}{l}\text { Meat intake } \\
\text { (servings } \\
\text { per week) }\end{array}$ & $\begin{array}{c}1.5 \\
(1.2)\end{array}$ & $1.4(0.9)$ & $\begin{array}{c}1.9 \\
(1.7)\end{array}$ & $\begin{array}{l}1.2 \\
(0.8)\end{array}$ & 0.020 & $\begin{array}{l}\text { Colombo } \\
\text { Kandy } \\
\text { Matara }\end{array}$ & $\begin{array}{l}0.08 \\
0.26\end{array}$ & $\begin{array}{l}0.08 \\
\mathbf{0 . 0 1}\end{array}$ & $\begin{array}{l}0.26 \\
\mathbf{0 . 0 1}\end{array}$ \\
\hline $\begin{array}{l}\text { Fish intake } \\
\text { (servings } \\
\text { per week) }\end{array}$ & $\begin{array}{l}10.8 \\
(5.7)\end{array}$ & 13.1 (4.3) & $\begin{array}{c}6.2 \\
(5.4)\end{array}$ & $\begin{array}{l}12.8 \\
(4.5)\end{array}$ & 0.000 & $\begin{array}{l}\text { Colombo } \\
\text { Kandy } \\
\text { Matara }\end{array}$ & $\begin{array}{l}\mathbf{0 . 0 0} \\
0.74\end{array}$ & $\begin{array}{l}0.00 \\
0.00\end{array}$ & $\begin{array}{l}0.74 \\
\mathbf{0 . 0 0}\end{array}$ \\
\hline $\begin{array}{l}\text { Eggs } \\
\text { (number } \\
\text { per week) }\end{array}$ & $\begin{array}{l}2.3 \\
(1.8)\end{array}$ & $1.8(1.4)$ & $\begin{array}{c}2.8 \\
(1.7)\end{array}$ & $\begin{array}{c}2.4 \\
(2.0)\end{array}$ & 0.022 & $\begin{array}{l}\text { Colombo } \\
\text { Kandy } \\
\text { Matara }\end{array}$ & $\begin{array}{l}\mathbf{0 . 0 0} \\
0.10\end{array}$ & $\begin{array}{l}\mathbf{0 . 0 0} \\
0.31\end{array}$ & $\begin{array}{l}0.10 \\
0.31\end{array}$ \\
\hline $\begin{array}{l}\text { Age of } \\
\text { infants } \\
\text { (weeks) }\end{array}$ & $\begin{array}{l}9.1 \\
(1.5)\end{array}$ & $8.1(1.4)$ & $\begin{array}{c}9.9 \\
(1.3)\end{array}$ & $\begin{array}{c}9.2 \\
(1.1)\end{array}$ & 0.000 & $\begin{array}{l}\text { Colombo } \\
\text { Kandy } \\
\text { Matara }\end{array}$ & $\begin{array}{l}0.00 \\
0.00\end{array}$ & $\begin{array}{l}0.00 \\
0.01\end{array}$ & $\begin{array}{l}0.00 \\
0.01\end{array}$ \\
\hline
\end{tabular}

to breast-milk findings, RBC monounsaturated FA was significantly higher, and saturated FA significantly lower, in the infants from Kandy. Of the EFA, while $\omega$-3 ALA levels did not differ by location, $\omega$-6 LA levels were significantly higher in Kandy than in Colombo or Matara. Of the LCPUFA, also in contrast to breast-milk findings, levels of $\omega$-3 LCPUFAs (EPA, DHA) showed no difference between the three locations, except for a lower EPA level recorded in Matara. Again in contrast to breast-milk findings, levels of $\omega-6$ ARA were significantly different in each location, highest in Kandy, intermediate in Colombo, and lowest in Matara, this sequence mirroring the $\omega$-6EFA(i.e. LA) sequence.

There were 119 mother-child pairs from which paired BM DHA and RBC DHA data was available. The mean (SD) BM DHA in these paired data was 0.54\% (0.25). No correlation between BM-DHA and infant RBC-DHA was found within these mother-infant pairs ( $\mathrm{r}=0.04, p=0.67)$.

\section{Discussion}

EFA (i.e. LA and ALA) levels in the breast-milk of mothers did not vary significantly between the three locations. This is as expected, because the mothers in each group had unrestricted dietary access to similar plantbased foods. However our EFA values are rather lower than those some others have reported, which we speculate may reflect the widespread use of coconut oil (which has a lower EFA content than many plant oils) in Sri Lankan cooking [3].

Similarly the levels of the n-6 LCPUFA, ARA, are also not different, probably reflecting either equal dietary access to animal-sourced food, or equal ability to synthesize this LCPUFA from the parent EFA (i.e. LA). ARA levels were within the limits described in other parts of the world [5].

Of the n-3 LCPUFA, EPA was higher in Matara, the location with easiest access to sea-fish, than the other two centers. DHA levels in all 3 groups differed significantly as described in other studies, and are well within the ranges described in the world literature [5]. The mean DHA levels in our groups corresponded with the availability of fish, and the individual mother's DHA levels in her breast-milk significantly correlated with her fish intake. 
Table 2. Breast-milk FA levels as \% of total FA

\begin{tabular}{|c|c|c|c|c|c|c|c|c|c|}
\hline & \multirow[t]{2}{*}{$\begin{array}{c}\text { All } \\
\mathrm{n}=136\end{array}$} & \multirow[t]{2}{*}{$\begin{array}{c}\text { Colombo } \\
\mathrm{n}=47\end{array}$} & \multirow[t]{2}{*}{$\begin{array}{c}\text { Kandy } \\
\mathrm{n}=44\end{array}$} & \multirow[t]{2}{*}{$\begin{array}{c}\text { Matara } \\
\mathrm{n}=45\end{array}$} & \multirow[t]{2}{*}{$\begin{array}{l}\text { ANOVA } \\
P \text { values }\end{array}$} & \multicolumn{4}{|c|}{$\begin{array}{c}\text { Unpaired } t \text { test } \\
\text { two-tailed } P \text { values }\end{array}$} \\
\hline & & & & & & & Colombo & Kandy & Matara \\
\hline Saturated & $\begin{array}{l}61.44 \\
(5.63)\end{array}$ & $\begin{array}{l}59.54 \\
(4.64)\end{array}$ & $\begin{array}{l}62.77 \\
(6.32)\end{array}$ & $\begin{array}{l}62.12 \\
(5.45)\end{array}$ & 0.014 & $\begin{array}{l}\text { Colombo } \\
\text { Kandy } \\
\text { Matara }\end{array}$ & $\begin{array}{l}0.01 \\
0.02\end{array}$ & $\begin{array}{l}\mathbf{0 . 0 1} \\
0.60\end{array}$ & 0.02 \\
\hline $\begin{array}{l}\text { Mono } \\
\text { unsaturated }\end{array}$ & $\begin{array}{l}22.93 \\
(4.00)\end{array}$ & $\begin{array}{l}24.51 \\
(3.87)\end{array}$ & $\begin{array}{l}22.18 \\
(3.62)\end{array}$ & $\begin{array}{l}22.00 \\
(4.06)\end{array}$ & 0.003 & $\begin{array}{l}\text { Colombo } \\
\text { Kandy } \\
\text { Matara }\end{array}$ & $\begin{array}{l}0.00 \\
0.00\end{array}$ & $\begin{array}{l}\mathbf{0 . 0 0} \\
0.83\end{array}$ & $\begin{array}{l}\mathbf{0 . 0 0} \\
0.83\end{array}$ \\
\hline Total n-3 & $\begin{array}{l}1.17 \\
(0.57)\end{array}$ & $\begin{array}{l}1.14 \\
(0.37)\end{array}$ & $\begin{array}{c}0.89 \\
(0.38)\end{array}$ & $\begin{array}{l}1.47 \\
(0.74)\end{array}$ & 0.000 & $\begin{array}{l}\text { Colombo } \\
\text { Kandy } \\
\text { Matara }\end{array}$ & $\begin{array}{l}0.00 \\
0.01\end{array}$ & $\begin{array}{l}0.00 \\
0.00\end{array}$ & $\begin{array}{l}0.01 \\
0.00\end{array}$ \\
\hline Total n-6 & $\begin{array}{l}6.71 \\
(1.81)\end{array}$ & $\begin{array}{l}6.86 \\
(1.69)\end{array}$ & $\begin{array}{c}6.27 \\
(1.94)\end{array}$ & $\begin{array}{l}6.98 \\
(1.75)\end{array}$ & 0.140 & $\begin{array}{l}\text { Colombo } \\
\text { Kandy } \\
\text { Matara }\end{array}$ & $\begin{array}{l}0.12 \\
0.74\end{array}$ & $\begin{array}{l}0.12 \\
0.07\end{array}$ & $\begin{array}{l}0.74 \\
0.07\end{array}$ \\
\hline LA (18:2n-6) & $\begin{array}{c}5.59 \\
(1.70)\end{array}$ & $\begin{array}{c}5.69 \\
(1.59)\end{array}$ & $\begin{array}{c}5.21 \\
(1.87)\end{array}$ & $\begin{array}{c}5.85 \\
(1.60)\end{array}$ & 0.181 & $\begin{array}{l}\text { Colombo } \\
\text { Kandy } \\
\text { Matara }\end{array}$ & $\begin{array}{l}0.19 \\
0.63\end{array}$ & $\begin{array}{l}0.19 \\
0.09\end{array}$ & $\begin{array}{l}0.63 \\
0.09\end{array}$ \\
\hline $\begin{array}{l}\text { ALA } \\
(18: 3 n-3)\end{array}$ & $\begin{array}{c}0.32 \\
(0.11)\end{array}$ & $\begin{array}{c}0.32 \\
(0.09)\end{array}$ & $\begin{array}{c}0.30 \\
(0.08)\end{array}$ & $\begin{array}{c}0.34 \\
(0.14)\end{array}$ & 0.212 & $\begin{array}{l}\text { Colombo } \\
\text { Kandy } \\
\text { Matara }\end{array}$ & $\begin{array}{l}0.27 \\
0.42\end{array}$ & $\begin{array}{l}0.27 \\
0.10\end{array}$ & $\begin{array}{l}0.42 \\
0.10\end{array}$ \\
\hline $\begin{array}{l}\text { ARA } \\
(20: 4 n-6)\end{array}$ & $\begin{array}{c}0.38 \\
(0.09)\end{array}$ & $\begin{array}{c}0.39 \\
(0.09)\end{array}$ & $\begin{array}{c}0.36 \\
(0.09)\end{array}$ & $\begin{array}{l}0.39 \\
(0.09)\end{array}$ & 0.195 & $\begin{array}{l}\text { Colombo } \\
\text { Kandy } \\
\text { Matara }\end{array}$ & $\begin{array}{l}0.12 \\
1.00\end{array}$ & $\begin{array}{l}0.12 \\
0.12\end{array}$ & $\begin{array}{l}1.00 \\
0.12\end{array}$ \\
\hline $\begin{array}{l}\text { EPA } \\
(20: 5 n-3)\end{array}$ & $\begin{array}{c}0.12 \\
(0.08)\end{array}$ & $\begin{array}{c}0.11 \\
(0.07)\end{array}$ & $\begin{array}{c}0.09 \\
(0.08)\end{array}$ & $\begin{array}{c}0.15 \\
(0.08)\end{array}$ & 0.001 & $\begin{array}{l}\text { Colombo } \\
\text { Kandy } \\
\text { Matara }\end{array}$ & $\begin{array}{l}0.21 \\
\mathbf{0 . 0 1}\end{array}$ & $\begin{array}{l}0.21 \\
\mathbf{0 . 0 0}\end{array}$ & $\begin{array}{l}0.01 \\
0.00\end{array}$ \\
\hline $\begin{array}{l}\text { DHA } \\
(22: 6 n-3)\end{array}$ & $\begin{array}{c}0.56 \\
(0.41)\end{array}$ & $\begin{array}{c}0.53 \\
(0.24)\end{array}$ & $\begin{array}{c}0.37 \\
(0.24)\end{array}$ & $\begin{array}{c}0.79 \\
(0.56)\end{array}$ & 0.000 & $\begin{array}{l}\text { Colombo } \\
\text { Kandy } \\
\text { Matara }\end{array}$ & $\begin{array}{l}0.00 \\
0.00\end{array}$ & $\begin{array}{l}0.00 \\
0.00\end{array}$ & $\begin{array}{l}0.00 \\
0.00\end{array}$ \\
\hline
\end{tabular}

In the range of BM DHA we studied in the matchedpairs (mean $0.54 \%$, SD $0.25 \%$ ), the infant's RBC-DHA did not vary with the DHA levels in the mother's milk. This was not surprising in view of the naturally high BM DHA. Gibson first reported that while BM DHA correlated with infant DHA levels, the relationship was curvilinear and saturated around $0.8 \%$ BM DHA, above which there was little change in infant DHA [6]. The data of Birch showed that most of the incorporation of DHA into the infant's RBC actually occurred at relatively lower levels of ingested DHA, i.e. below $0.32 \%$ DHA [7]. When infants were fed formula with double or triple the initial formula DHA content of $0.32 \%$, the largest increase of RBC DHA over control formula (with 0\% DHA), was found to have occurred at the lowest step (0.32\% DHA). Increasing the formula DHA levels from control to $0.32 \%, 0.64 \%$, or even $0.96 \%$ DHA resulted in infant RBC DHA levels of 2.4, 3.0 and 3.3 times that seen in the control group respectively. In our study, the median level in the BM group $(0.54 \%$ DHA) was already higher than this initial level studied by Birch. It is therefore likely that for many of the motherinfant pairs in our study, the breast-milk DHA levels would have reached or even exceeded the level where further infant incorporation would have been small at best.

We found that $\omega-6$ levels in infant RBC varied by location, even though the breast-milk levels did not. This same pattern (highest in Kandy, intermediate in Colombo, and lowest in Matara) was seen both with the EFA (i.e. LA) and with the LCPUFA (i.e. ARA). It is now generally accepted that the fatty acid desaturase enzymes involved in the metabolism of LCPUFA from their precursor molecules are subject to mutations, and these changes can have an influence on both the $\omega-6$ and (less so) the $\omega-3$ FA. A recent review on the effect of genetic variation in the relevant genes suggested that their effects on $\omega-3$ LCPUFA levels were likely to be minor, as DHA concentrations are primarily determined by the dietary supply of preformed DHA, while their effects on $\omega$-6 LCPUFA levels were likely to be much more marked "genetic variants explained as much as $28.5 \%$ of the variations in serum arachidonic acid contents...." [2]. Whether such genetic variations, or differences in early weaning practice in the different locations, might have contributed to the differences in $\omega-6$ FA levels we observed in our infant RBC data, remains unknown at this stage. 
Table 3. RBC FA levels (from infant heel-prick, as \% of total FA)

\begin{tabular}{|c|c|c|c|c|c|c|c|c|c|}
\hline & \multirow[t]{2}{*}{$\begin{array}{c}\text { All } \\
\mathrm{n}=127\end{array}$} & \multirow[t]{2}{*}{$\begin{array}{c}\text { Colombo } \\
\mathrm{n}=43\end{array}$} & \multirow[t]{2}{*}{$\begin{array}{c}\text { Kandy } \\
\mathrm{n}=45\end{array}$} & \multirow[t]{2}{*}{$\begin{array}{c}\text { Matara } \\
\mathrm{n}=39\end{array}$} & \multirow[t]{2}{*}{$\begin{array}{l}\text { ANOVA } \\
P \text { values }\end{array}$} & \multicolumn{4}{|c|}{$\begin{array}{c}\text { Unpaired } t \text { test } \\
\text { two-tailed } P \text { values }\end{array}$} \\
\hline & & & & & & & Colombo & Kandy & Matara \\
\hline Saturated & $\begin{array}{c}66.22 \\
(11.50)\end{array}$ & $\begin{array}{c}66.69 \\
(11.65)\end{array}$ & $\begin{array}{l}60.98 \\
(8.40)\end{array}$ & $\begin{array}{c}71.75 \\
(11.93)\end{array}$ & 0.000 & $\begin{array}{l}\text { Colombo } \\
\text { Kandy } \\
\text { Matara }\end{array}$ & $\begin{array}{l}\mathbf{0 . 0 1} \\
0.06\end{array}$ & $\begin{array}{l}0.01 \\
0.00\end{array}$ & $\begin{array}{l}0.06 \\
\mathbf{0 . 0 0}\end{array}$ \\
\hline $\begin{array}{l}\text { Mono } \\
\text { unsaturated }\end{array}$ & $\begin{array}{l}13.42 \\
(5.00)\end{array}$ & $\begin{array}{c}12.48 \\
(3.83)\end{array}$ & $\begin{array}{l}16.31 \\
(4.13)\end{array}$ & $\begin{array}{c}11.13 \\
(5.54)\end{array}$ & 0.000 & $\begin{array}{l}\text { Colombo } \\
\text { Kandy } \\
\text { Matara }\end{array}$ & $\begin{array}{l}\mathbf{0 . 0 0} \\
0.20\end{array}$ & $\begin{array}{l}0.00 \\
0.00\end{array}$ & $\begin{array}{l}0.20 \\
\mathbf{0 . 0 0}\end{array}$ \\
\hline Total n-3 & $\begin{array}{c}2.43 \\
(1.44)\end{array}$ & $\begin{array}{c}2.74 \\
(1.69)\end{array}$ & $\begin{array}{c}2.44 \\
(1.27)\end{array}$ & $\begin{array}{c}2.07 \\
(1.26)\end{array}$ & 0.108 & $\begin{array}{l}\text { Colombo } \\
\text { Kandy } \\
\text { Matara }\end{array}$ & $\begin{array}{l}0.35 \\
\mathbf{0 . 4 7}\end{array}$ & $\begin{array}{l}0.35 \\
0.19\end{array}$ & $\begin{array}{l}\mathbf{0 . 4 7} \\
0.19\end{array}$ \\
\hline Total n-6 & $\begin{array}{l}11.33 \\
(5.34)\end{array}$ & $\begin{array}{l}10.79 \\
(4.65)\end{array}$ & $\begin{array}{l}14.86 \\
(4.64)\end{array}$ & $\begin{array}{c}7.85 \\
(4.26)\end{array}$ & 0.000 & $\begin{array}{l}\text { Colombo } \\
\text { Kandy } \\
\text { Matara }\end{array}$ & $\begin{array}{l}0.00 \\
0.00\end{array}$ & $\begin{array}{l}0.00 \\
0.00\end{array}$ & $\begin{array}{l}0.00 \\
0.00\end{array}$ \\
\hline $\begin{array}{l}\text { LA } \\
(18: 2 n-6)\end{array}$ & $\begin{array}{c}5.45 \\
(2.86)\end{array}$ & $\begin{array}{c}4.55 \\
(1.97)\end{array}$ & $\begin{array}{c}7.82 \\
(2.54)\end{array}$ & $\begin{array}{c}3.71 \\
(2.15)\end{array}$ & 0.000 & $\begin{array}{l}\text { Colombo } \\
\text { Kandy } \\
\text { Matara }\end{array}$ & $\begin{array}{l}\mathbf{0 . 0 0} \\
0.07\end{array}$ & $\begin{array}{l}0.00 \\
0.00\end{array}$ & $\begin{array}{l}0.07 \\
\mathbf{0 . 0 0}\end{array}$ \\
\hline $\begin{array}{l}\text { ALA } \\
(18: 3 n-3)\end{array}$ & $\begin{array}{c}0.28 \\
(0.30)\end{array}$ & $\begin{array}{c}0.34 \\
(0.48)\end{array}$ & $\begin{array}{c}0.24 \\
(0.12)\end{array}$ & $\begin{array}{c}0.26 \\
(0.11)\end{array}$ & 0.252 & $\begin{array}{l}\text { Colombo } \\
\text { Kandy } \\
\text { Matara }\end{array}$ & $\begin{array}{l}0.18 \\
0.31\end{array}$ & $\begin{array}{l}0.18 \\
0.43\end{array}$ & $\begin{array}{l}0.31 \\
0.43\end{array}$ \\
\hline $\begin{array}{l}\text { ARA } \\
(20: 4 n-6)\end{array}$ & $\begin{array}{c}4.15 \\
(2.06)\end{array}$ & $\begin{array}{c}4.33 \\
(2.09)\end{array}$ & $\begin{array}{c}4.97 \\
(1.77)\end{array}$ & $\begin{array}{l}3.01 \\
(1.85)\end{array}$ & 0.000 & $\begin{array}{l}\text { Colombo } \\
\text { Kandy } \\
\text { Matara }\end{array}$ & $\begin{array}{l}0.12 \\
\mathbf{0 . 0 0}\end{array}$ & $\begin{array}{l}0.12 \\
\mathbf{0 . 0 0}\end{array}$ & $\begin{array}{l}0.00 \\
0.00\end{array}$ \\
\hline $\begin{array}{l}\text { EPA } \\
(20: 5 n-3)\end{array}$ & $\begin{array}{c}0.14 \\
(0.21\end{array}$ & $\begin{array}{c}0.17 \\
(0.32)\end{array}$ & $\begin{array}{c}0.14 \\
(0.13)\end{array}$ & $\begin{array}{c}0.09 \\
(0.09)\end{array}$ & 0.219 & $\begin{array}{l}\text { Colombo } \\
\text { Kandy } \\
\text { Matara }\end{array}$ & $\begin{array}{l}0.57 \\
0.14\end{array}$ & $\begin{array}{c}0.57 \\
\mathbf{0 . 0 4 6}\end{array}$ & $\begin{array}{c}0.14 \\
\mathbf{0 . 0 4 6}\end{array}$ \\
\hline $\begin{array}{l}\text { DHA } \\
(22: 6 n-3)\end{array}$ & $\begin{array}{c}0.76 \\
(1.05)\end{array}$ & $\begin{array}{c}1.85 \\
(1.04)\end{array}$ & $\begin{array}{c}1.81 \\
(0.96)\end{array}$ & $\begin{array}{c}1.61 \\
(1.16)\end{array}$ & 0.548 & $\begin{array}{l}\text { Colombo } \\
\text { Kandy } \\
\text { Matara }\end{array}$ & $\begin{array}{l}0.85 \\
0.33\end{array}$ & $\begin{array}{l}0.85 \\
0.39\end{array}$ & $\begin{array}{l}0.33 \\
0.39\end{array}$ \\
\hline
\end{tabular}

We therefore conclude that limited access to seafish is enough to result in relatively lower levels of important $\omega$-3 LCPUFA in women of child-bearing age. Though these results have been reported by others before, this study emphasizes the importance of dietary counseling of such women to consume more sea-fish, when this is available and affordable to them.

\section{Acknowledgements}

This study was supported by an educational grant from Mead Johnson Nutritionals, Asia-Pacific region.

\section{References}

1. Martinez M. Tissue levels of polyunsaturated fatty acids in early human development. Journal of Pediatrics 1992; 120: $129-38$.

2. Glaser C, Lattka E, Rzehak P, et al. Genetic variation in polyunsaturated fatty acid metabolism and its potential relevance for human development and health. Maternal and Child Nutrition 2011; 7: 27-40.
3. Sanders TA, Reddy S. The influence of a vegetarian diet on the fatty acid composition of human milk and the essential fatty acid status of the infant. Journal of Pediatrics 1992; 120: S71-7.

4. Yuhas R, Pramuk K, Lien EL. Human milk fatty acid composition from nine countries varies most in DHA. Lipids 2006; 41: 851-8.

5. Brenna JT, Varamini B, Jensen RG, et al. Docosahexaenoic and arachidonic acid concentrations in human breast milk worldwide. American Journal of Clinical Nutrition 2007; 85: 1457-64.

6. Gibson RA, Neumann MA, Makrides M. Effect of increasing breast milk docosahexaenoic acid on plasma and erythrocyte phospholipid fatty acids and neural indices of exclusively breast fed infants. European Journal of Clinical Nutrition 1997; 51: S78-84.

7. Birch EE, Carlson SE, Hoffman DE, et al. The DIAMOND (DHA Intake and Measurement of Neural Development) study: A double-masked, randomized controlled clinical trial of the maturation of infant visual acuity as a function of the dietary level of docosahexaenoic acid. American Journal of Clinical Nutrition 2010; 91: 848-59. 